\title{
EFISIENSI ALOKATIF PEMBESARAN IKAN MUJAIR DI DESA KEBOCORAN KECAMATAN KEDUNG BANTENG KABUPATEN BANYUMAS
}

\author{
Allocative Efficiency of Tilapia Fish Enlargement in Kebocoran Village \\ Kedung Banteng Subdistrict Banyumas Regency \\ Veninda Ayu Utami*, Agus Santosa, Budiarto \\ Program Studi Agribisnis Fakultas Pertanian \\ Universitas Pembangunan Nasional "Veteran" Yogyakarta \\ Jl. SWK 104, Condong Catur, Depok, Sleman, Yogyakarta, Indonesia 55283 \\ email korespondensi : venindaayu13@gmail.com
}

Diterima tanggal : 21 Maret 2019; Disetujui tanggal : 29 Mei 2019

\begin{abstract}
This research aims to 1) analyze the production factors which needed in tilapia fish enlargement business on the Ulam Sari Makmur Fish Group Cultivators, 2) analyze the optimal use of production factors in tilapia fish enlargement business on the Ulam Sari Makmur Fish Group Cultivators. The basic research method used is descriptive. The method of selecting a research area is a purposive method. The method of taking respondents is a census. To analyze the effect of production factors using the analysis of cobb-douglas production functions with multiple linear regression analysis. To optimize the level of optimization of the use of production factors using allocative efficiency analysis. The results of the research at Ulam Sari Makmur Fish Group Cultivators in Kebocoran village, Kedung Banteng subdistrict, Banyumas Regency showed that 1) seed and pellet feed were related positive to production, while dolomite and labor hadn't a relationship with tilapia fish production, 2) the use of seed and pellet production factors is not optimum, it is necessary to add inputs so that the optimum number of inputs is $66.8 \mathrm{~kg} / 150 \mathrm{~m}^{2}$ and $173.7 \mathrm{~kg} / 150 \mathrm{~m}^{2}$. The use of dolomite production factors and labor is not yet optimum, it is necessary to reduce inputs so that the optimum number of inputs is $3.70 \mathrm{~kg} / 150 \mathrm{~m}^{2}$ and -0.62 hok.
\end{abstract}

Keywords: Allocative Efficiency, Production, Production Factors, Tilapia

\begin{abstract}
ABSTRAK
Penelitian ini bertujuan untuk 1) menganalisis faktor-faktor produksi usaha pembesaran ikan mujair Kelompok Pembudidaya Ikan Ulam Sari Makmur, 2) menganalisis penggunaan faktor-faktor produksi yang optimum pada usaha pembesaran ikan mujair Kelompok Pembudidaya Ikan Ulam Sari Makmur. Metode dasar penelitian yang digunakan adalah metode deskriptif. Metode penentuan daerah penelitian yang digunakan adalah purposive method. Metode pengambilan responden yang digunakan adalah sensus. Untuk menganalisis
\end{abstract}


pengaruh dari faktor-faktor produksi menggunakan analisis fungsi produksi cobb-douglas dengan analisis regresi linear berganda. Sedangkan untuk menganalisis tingkat optimasi penggunaan faktor-faktor produksi menggunakan analisis efisiensi alokatif. Hasil penelitian yang dilakukan pada Kelompok Pembudidaya Ikan Ulam Sari Makmur di Desa Kebocoran, Kecamatan Kedung Banteng, Kabupaten Banyumas menunjukkan bahwa 1) benih dan pakan pelet memiliki pengaruh positif terhadap produksi ikan mujair, sedangkan dolomit dan tenaga kerja tidak memiliki pengaruh terhadap produksi ikan mujair, 2) penggunaan faktor produksi benih dan pelet tidak optimum, perlu dilakukan penambahan input sehingga jumlah input optimumnya menjadi sebesar 66,8 $\mathrm{kg} / 150 \mathrm{~m}^{2}$ dan $173,7 \mathrm{~kg} / 150 \mathrm{~m}^{2}$. Penggunaan faktor produksi dolomit dan tenaga kerja belum optimum, perlu dilakukan pengurangan input sehingga jumlah input optimumnya sebesar $3,70 \mathrm{~kg} / 150 \mathrm{~m}^{2}$ dan $-0,62$ hok.

Kata kunci: Efisiensi Alokatif, Faktor Produksi, Produksi, Ikan Mujair

\section{PENDAHULUAN}

Sektor pertanian memegang peran strategis sebagai penggerak perekonomian nasional. Peran strategis pertanian tersebut digambarkan dari besarnya PDB pertanian terhadap PDB nasional yakni $14 \%$ per tahun dari masing-masing sektor pertanian. Salah satu sub sektor pertanian yang memberi kontribusi terbesar terhadap pembentukan PDB sektor pertanian yaitu sub sektor perikanan. Data yang diperoleh KKP (2017), menunjukkan total produksi perikanan nasional pada tahun 2017 mencapai 24,21 juta ton. Produksi tersebut terdiri dari produksi perikanan budidaya sebesar 17,22 juta ton dan produksi perikana tangkap sebesar 6,99 juta ton.

Kabupaten Banyumas merupakan salah satu daerah di provinsi Jawa Tengah yang memiliki potensi dalam penghasil produk perikanan air tawar. Hal tersebut didukung oleh berlimpahnya air yang diperoleh langsung dari gunung Slamet ataupun dari bendungan Gerak Serayu. Ketersediaan air yang berlimpah tersebut cocok untuk kegiatan usaha ikan air tawar. Ada 10 kecamatan di Kabupaten Banyumas yang menjadi kawasan minapolitan, yaitu Kemranjen, Ajibarang, Pekuncen, Cilongok, Karang Lewas, Kedung Banteng, Baturraden, Sumbang, Kembaran, dan Sokaraja.

Salah satu desa yang melakukan usaha ikan air tawar di Kecamatan

Kedung Banteng adalah Desa Kebocoran. Di Desa Kebocoran terdapat 
kelompok pembudidaya ikan (pokdakan) air tawar yang masih aktif hingga saat ini. Pokdakan Ulam Sari Makmur melakukan kegiatan usaha pembesaran ikan mujair. Anggota pokdakan Ulam Sari Makmur sebagian besar merupakan buruh tani dengan penghasilan kecil.

Menurut Soekartawi (2016), efisiensi alokatif adalah usaha untuk mengoptimalkan penggunaan faktor-faktor produksi agar tingkat produksi berada dalam keadaan optimum. Prinsip efisiensi alokatif penggunaan faktorfaktor produksi adalah bagaimana menggunakan faktor-faktor produksi seefisien mungkin. Tingkat penggunaan produksi yang berbeda-beda akan berpengaruh pada usaha pembesaran ikan mujair. Sehingga perlu dilakukan penghitungan yang tepat agar faktor-faktor produksi yang digunakan dapat terukur dengan baik. Pengadaan modal sendiri yang dilakukan oleh anggota pokdakan mengakibatkan pengalokasian modal untuk faktor-faktor produksi menjadi terbatas. Sehingga perlu dilakukan pengkajian terhadap faktor-faktor produksi apa saja yang berpengaruh terhadap kegiatan budidaya pembesaran ikan mujair agar penggunaan faktor-faktor produksi dapat dilakukan secara optimum.

\section{METODE PENELITIAN}

Metode dasar yang digunakan dalam penelitian ini adalah metode deskriptif yang berusaha menggambarkan dan menginterpretasikan obyek sesuai dengan apa adanya. Daerah penelitian ini ditentukan secara sengaja (purposive method) dengan pertimbangan bahwa Pokdakan Ulam Sari Makmur merupakan kelompok pembudidaya ikan di Desa Kebocoran dengan jumlah anggota tetap yang aktif terbanyak, yaitu berjumlah 18 orang. Pengambilan responden menggunakan metode sensus, yaitu semua responden yang ada diambil seluruhnya dari total populasi yang tersedia. Data yang digunakan data primer dan data sekunder. Metode pengumpulan data yang digunakan observasi, wawancara, kuesioner, dan pencatatan.

\section{Fungsi Produksi}


Untuk menganalisis fungsi produksi, yang merupakan fungsi yang menjelaskan hubungan sebab-akibat antara produksi dan faktor-faktor produksi yang mempengaruhinya. Dalam penelitian ini digunakan analisis fungsi produksi Cobb-Douglas sebagai berikut:

$\mathrm{Y}=\mathrm{b}_{0} \mathrm{X}_{1}^{\mathrm{b} 1} \mathrm{X}_{2}{ }^{\mathrm{b} 2} \mathrm{X}_{3}{ }^{\mathrm{b} 3} \mathrm{X}_{4}{ }^{\mathrm{b} 4} \mathrm{e}$

Dari fungsi Cobb-Douglas di atas, kemudian diubah ke bentuk linear, sehingga fungsi produksi menjadi sebagai berikut:

$\mathrm{LnY}=\ln \mathrm{b}_{0}+\mathrm{b}_{1} \ln \mathrm{X}_{1}+\mathrm{b}_{2} \ln \mathrm{X}_{2}+\mathrm{b}_{3} \ln \mathrm{X}_{3}+\mathrm{b}_{4} \ln \mathrm{X}_{4}$

Keterangan:

\begin{tabular}{|c|c|}
\hline Y & $=$ Hasil produksi $(\mathrm{kg})$ \\
\hline $\mathrm{X}_{1}$ & $=\operatorname{Benih}\left(\mathrm{kg} / \mathrm{m}^{2}\right)$ \\
\hline$X_{2}$ & $=$ Pakan pelet $(\mathrm{kg})$ \\
\hline $\mathrm{X}_{3}$ & $=$ Dolomit $(\mathrm{kg})$ \\
\hline $\mathrm{X}_{4}$ & $=$ Tenaga Kerja \\
\hline $\mathrm{b}_{0}$ & $=$ Intercept \\
\hline $\mathrm{b}_{1}$ & $=$ Koefisien regresi benih \\
\hline $\mathrm{b}_{2}$ & $=$ Koefisien regresi pakan pelet \\
\hline $\mathrm{b}_{3}$ & $=$ Koefisien regresi dolomit \\
\hline $\mathrm{b}_{4}$ & $=$ Koefisien regresi tenaga kerja \\
\hline
\end{tabular}

Pengujian hipotesis:

a. Nilai koefisien determinan $\left(\mathrm{R}^{2}\right)$ digunakan untuk melihat sejauh mana besar keragaman yang dapat diterangkan oleh variabel bebas terhadap variabel tidak bebas. Koefisien determinan dirumuskan sebagai berikut :

$$
\mathrm{R}^{2}=\frac{\mathrm{JKR}}{\mathrm{JKT}}
$$

Keterangan:

JKR = Jumlah kuadrat regresi

JKT = Jumlah kuadrat total

$\mathrm{R}^{2} \quad=$ Koefisien determinasi

b. Uji statistik F digunakan untuk mengetahui secara langsung faktor-faktor produksi yang berpengaruh terhadap hasil produksi. Uji $\mathrm{F}$ sendiri dapat dirumuskan sebagai berikut:

Hipotesis: 


$$
\begin{aligned}
& \text { Ho } ; \beta 1=\beta 2=\ldots=\beta 4=0 \\
& \text { H1; } \beta 1 \neq \beta 2 \neq \ldots \neq \beta 4 \neq 0 \\
& \text { F-hitung }=\frac{\frac{\mathrm{R}^{2}}{\mathrm{k}-1}}{\left(1-\mathrm{R}^{2}\right) /(\mathrm{n}-\mathrm{k})}
\end{aligned}
$$

\section{Keterangan:}

$\mathrm{R}^{2} \quad=$ Koefisien determinasi

$\mathrm{k} \quad=$ Jumlah variabel

$\mathrm{n} \quad=$ Jumlah pengamatan

$\alpha \quad=$ Tingkat kepercayaan

Kriteria pengujian:

F-hitung > F-tabel [F $\alpha(\mathrm{k}-1, \mathrm{k}-\mathrm{n})]$, Ho ditolak.

F-hitung $\leq$ F-tabel [F $\alpha(\mathrm{k}-1, \mathrm{k}-\mathrm{n})]$, Ho diterima.

Apabila F-hitung lebih besar dari F-tabel, maka secara bersama-sama variabel bebas dalam produksi mempunyai pengaruh yang nyata terhadap hasil produksi. Sebaliknya, jika F-hitung lebih kecil daripada F-tabel, maka secara bersama-sama variabel bebas tidak berpengaruh nyata terhadap hasil produksi.

c. Nilai dari t-hitung dapat digunakan untuk mengetahui apakah koefisien regresi dari masing-masing variabel bebas yang dipakai secara terpisah berpengaruh terhadap variabel tidak bebas. Uji t dapat dirumuskan sebagai berikut:

Hipotesis:

Ho $; \beta 1=0$

$\mathrm{H} 1 ; \beta 1 \neq 0 ; \mathrm{i}: 1,2,3,4$

$\mathrm{t}$-hitung $=\frac{\mathrm{b}_{1}\left(\beta_{1}\right)}{\mathrm{Sb}_{1}}$

Keterangan:

$\mathrm{k}=$ Jumlah variabel

$\mathrm{b}_{1} \quad=$ Koefisien dugaan ke-i

$\beta_{1} \quad=$ Variabel ke-I yang dihipotesiskan

$\mathrm{Sb}_{1} \quad=$ Simpangan baku koefisien regresi

Kriteria pengujian: 
Utami et.al. / Jurnal Dinamika Sosial Ekonomi Vol.20 No.1, Juni 2019

t-hitung $>$ t-tabel [t $\alpha / 2,(n-k)]$, Ho ditolak

t-hitung $\leq \mathrm{t}$-tabel $[\mathrm{t} \alpha / 2$, (n-k)], Ho diterima

Jika Ho ditolak maka peubah bebas $\left(\mathrm{X}_{\mathrm{i}}\right)$ berpengaruh nyata terhadap peubah tidak bebas $(\mathrm{Y})$, dan jika Ho diterima maka peubah bebas $\left(\mathrm{X}_{\mathrm{i}}\right)$ tidak berpengaruh nyata terhadap peubah tidak bebas (Y).

\section{Efisiensi Alokatif}

Efisiensi alokasi dapat tercapai apabila perbandingan antara nilai produk marjinal (NPM) masing-masing input dengan harga inputnya sama dengan satu. Indeks efisiensi dari alokasi setiap faktor produksi $\left(\mathrm{k}_{\mathrm{i}}\right)$ dapat ditentukan sebagai berikut:

$\mathrm{k}_{\mathrm{i}}=\mathrm{bi} \cdot \frac{\mathrm{Y}}{\mathrm{Xi}} \cdot \frac{\mathrm{Py}_{\mathrm{y}}}{\mathrm{Pxi}_{\mathrm{i}}}$

Keterangan:

bi = elastisitas produksi faktor ke-i

$\mathrm{Y} \quad=$ produksi output

Py = harga output

$\mathrm{Xi} \quad=$ jumlah penggunaan faktor produksi ke-i

Pxi = harga faktor produksi ke-i

Kriteria yang digunakan:

a. Jika nilai $\mathrm{k}_{\mathrm{i}}=1$ atau NPM sama dengan harga input, maka penggunaan input tersebut sudah optimum.

b. Jika nilai $\mathrm{k}_{\mathrm{i}}<1$ atau NPM kurang dari harga input, maka penggunaan input tersebut belum optimum.

c. Jika nilai $\mathrm{k}_{\mathrm{i}}>1$ atau NPM lebih dari harga input, maka penggunaan input tersebut tidak optimum.

\section{HASIL DAN PEMBAHASAN}

\section{Penggunaan Faktor-faktor Produksi Pembesaran Ikan Mujair}

Faktor produksi yang digunakan dalam pembesaran ikan mujair terdiri dari benih, pakan pelet, dolomit, dan tenaga kerja. Keempat fakor produksi tersebut digunakan untuk kolam tanah dengan luas $150 \mathrm{~m}^{2}$. 
Utami et.al. / Jurnal Dinamika Sosial Ekonomi Vol.20 No.1, Juni 2019

Tabel 1. Rata-rata Penggunaan Faktor Produksi Pada Usaha Pembesaran Ikan Mujair di Desa Kebocoran Tahun 2018

\begin{tabular}{|c|c|c|c|c|c|c|c|}
\hline \multirow{2}{*}{ Variabel } & \multirow{2}{*}{ Satuan } & \multicolumn{3}{|c|}{$\begin{array}{l}\text { Penggunaan input } \\
\left(150 \mathrm{~m}^{2}\right)\end{array}$} & \multirow{2}{*}{$\begin{array}{c}\text { Rata- } \\
\text { rata } \\
(1.000 \\
\left.\mathrm{m}^{2}\right)\end{array}$} & \multicolumn{2}{|c|}{ Rekomendasi BSN } \\
\hline & & Min & Maks & $\begin{array}{l}\text { Rata- } \\
\text { rata }\end{array}$ & & $150 \mathrm{~m}^{2}$ & $1.000 \mathrm{~m}^{2}$ \\
\hline $\begin{array}{l}\text { Benih } \\
\text { (X1) }\end{array}$ & $\mathrm{kg}$ & 20,00 & 100,00 & 38,89 & 259,39 & 1.050 ekor & 7.000 ekor \\
\hline $\begin{array}{l}\text { Pakan } \\
\text { pelet (X2) }\end{array}$ & $\mathrm{kg}$ & 30,00 & 100,00 & 61,94 & 413,17 & 269,3 & $1.760,2$ \\
\hline $\begin{array}{l}\text { Dolomit } \\
\text { (X3) }\end{array}$ & $\mathrm{kg}$ & 10,00 & 20,00 & 12,50 & 83,38 & 37,5 & 250,0 \\
\hline $\begin{array}{l}\text { Tenaga } \\
\text { Kerja } \\
\text { (X4) }\end{array}$ & hok & 14,57 & 26,00 & 18,41 & 125,64 & - & - \\
\hline
\end{tabular}

Sumber: Analisis Data Primer, 2019

Menurut Sumartin (2017), pendugaan model fungsi produksi CobbDouglas menggunakan metode OLS bertujuan untuk mengetahui kinerja ratarata dari proses produksi usaha pembesaran ikan mujair yang dilakukan. Berikut ini tabel parameter pendugaan fungsi produksi menggunakan metode OLS.

Tabel 2. Hasil Analisis Regresi Faktor-Faktor Produksi Pada Usaha Pembesaran Ikan Mujair di Desa Kebocoran Tahun 2018

\begin{tabular}{lcr}
\hline \multicolumn{1}{c}{ Variabel } & $\mathrm{B}$ & $\mathrm{t}$ \\
\hline Konstanta & 0,773 & 0,796 \\
$\mathrm{X}_{1}$ (benih) & $0,563^{*}$ & 4,681 \\
$\mathrm{X}_{2}$ (pakan pelet) & $0,601^{*}$ & 3,768 \\
$\mathrm{X}_{3}$ (dolomit) & 0,003 & 0,19 \\
$\mathrm{X}_{4}$ (tenaga kerja) & $-0,360$ & $-1,136$ \\
\hline Adjusted R Square & & 0,879 \\
F $_{\text {hitung }}$ & & 31,947 \\
$\mathrm{~F}_{\text {tabel }}$ & & 3,18 \\
$\mathrm{t}_{\text {tabel }}(\alpha=0,05)$ & & 2,160 \\
\hline
\end{tabular}

Sumber: Analisis Data Primer, 2019

Keterangan $^{*}$ : Signifikan

Berdasarkan tabel 2. dapat diketahui bahwa nilai adjusted $R$ square yang diperoleh sebesar 0,879 hal ini berarti sebesar $87,9 \%$ produksi ikan mujair di Desa Kebocoran Kecamatan Kedung Banteng dipengaruhi oleh faktor produksi seperti benih, pakan pelet, dolomit, dan tenaga kerja. Sedangkan sisanya sebesar $12,1 \%$ dipengaruhi oleh faktor lain di luar penelitian. Namun secara individu, 
faktor produksi yang berpengaruh positif terhadap hasil produksi ikan mujair adalah benih dan pelet. Sedangkan dolomit dan tenaga kerja tidak berpengaruh terhadap hasil produksi ikan mujair. Menurut Sumartin (2018), penggunaan dolomit dan tenaga kerja seharusnya memiliki pengaruh terhadap hasil produksi ikan.

Nilai koefisien variabel $\mathrm{X}_{1}$ (benih) sebesar 0,563 yang berarti bahwa dengan penambahan jumlah benih sebanyak 1 persen dengan asumsi input yang lain dianggap tetap maka akan meningkatkan produksi pembesaran ikan mujair sebesar 0,563 persen. Nilai koefisien variabel $X_{2}$ (pakan pelet) sebesar 0,601 yang berarti bahwa dengan penambahan jumlah pakan pelet sebanyak 1 persen dengan asumsi input yang lain dianggap tetap maka akan meningkatkan produksi pembesaran ikan mujair sebesar 0,601 persen. Koefisien regresi $X_{1}$ dan $\mathrm{X}_{2}$ sejalan dengan penelitian Hidayatullah (2016) dan Fajriati (2018) yang menyatakan bahwa benih dan pakan memiliki pengaruh positif terhadap produksi pembesaran ikan. Nilai koefisien variabel $\mathrm{X}_{3}$ (dolomit) sebesar 0,003 yang berarti bahwa dengan penambahan jumlah dolomit sebanyak 1 persen dengan asumsi input yang lain dianggap tetap maka akan menambah produksi pembesaran ikan mujair sebesar 0,003 persen. Nilai koefisien variabel $\mathrm{X}_{4}$ (tenaga kerja) sebesar -0,360 yang berarti bahwa dengan penambahan jumlah tenaga kerja sebanyak 1 persen dengan asumsi input yang lain dianggap tetap maka akan menurunkan produksi pembesaran ikan mujair sebesar 0,360 persen, hal ini tidak sejalan dengan penelitian Negara (2017) yang menyatakan bahwa tenaga kerja memiliki pengaruh terdapat produksi pembesaran ikan, tenaga kerja yang berpengaruh merupakan tenaga kerja yang sudah terampil dalam melakukan pekerjaannya.

\section{Efiiensi Alokatif Faktor-Faktor Produksi Pembesaran Ikan Mujair}

Menurut Riani (2018), petani yang rasional dalam proses produksinya mempunyai tujuan untuk memperoleh keuntungan. Keuntungan akan maksimal apabila kombinasi penggunaan faktor-faktor produksi mencapai tingkat efisiensi 
Utami et.al. / Jurnal Dinamika Sosial Ekonomi Vol.20 No.1, Juni 2019

ekonomi tertinggi. Kondisi tersebut tercapai apabila perbandingan antara produk marginal (NMPxi) dengan harga faktor produksi (Pxi) sama dengan satu.

Tabel 3. Rasio NPMxi dan Pxi Faktor-Faktor Produksi Pada Usaha Pembesaran Ikan Mujair di Desa Kebocoran Tahun 2018

\begin{tabular}{llcrrrl}
\hline $\begin{array}{c}\text { Faktor } \\
\text { Produksi }\end{array}$ & $\overline{\mathbf{Y}}$ & Py & NPMxi & Pxi & Ki & Kriteria \\
\hline $\mathrm{X}_{1}$ & 71,94 & $25.666,67$ & $26.730,7$ & $15.555,56$ & 1,71 & $\begin{array}{l}\text { Tidak } \\
\text { optimum }\end{array}$ \\
$\mathrm{X}_{2}$ & 71,94 & $25.666,67$ & $17.916,1$ & $6.388,89$ & 2,80 & $\begin{array}{l}\text { Tidak } \\
\text { optimum }\end{array}$ \\
$\mathrm{X}_{3}$ & 71,94 & $25.666,67$ & 443,2 & $1.500,00$ & 0,30 & $\begin{array}{l}\text { Belum } \\
\text { optimum }\end{array}$ \\
$\mathrm{X}_{4}$ & 71,94 & $25.666,67$ & $-36.666,67$ & $1.063 .611,11$ & $-0,03$ & $\begin{array}{l}\text { Belum } \\
\text { optimum }\end{array}$ \\
\hline
\end{tabular}

Sumber: Analisis Data Primer, 2019

Berdasarkan tabel 3, dapat diketahui bahwa rasio NPMxi/Pxi pada variabel $X_{1}$ (benih) dan $X_{2}$ (pakan pelet) sebesar 1,71 dan 2,80. Hasil tersebut menyatakan bahwa faktor produksi benih dan pakan pelet tidak optimum dikarenakan NPMxi/Pxi bernilai lebih dari satu. Artinya anggota Pokdakan Ulam Sari Makmur masih bisa melakukan penambahan jumlah benih dan pakan pelet yang digunakan. Faktor produksi variabel $\mathrm{X}_{3}$ (dolomit) dan $\mathrm{X}_{4}$ (tenaga kerja) menunjukkan bahwa rasio NPMxi/Pxi sebesar 0,3 dan -0,03. Hasil tersebut menyatakan bahwa faktor produksi dolomit dan tenaga kerja belum optimum dikarenakan NPMxi/Pxi bernilai kurang dari satu. Artinya anggota Pokdakan Ulam Sari Makmur masih bisa melakukan pengurangan jumlah dolomit dan tenaga kerja yang digunakan.

Tabel 4. Penggunaan Input Optimal Faktor-Faktor Produksi Pada Usaha Pembesaran Ikan Mujair di Desa Kebocoran Tahun 2018

\begin{tabular}{lllrrr}
\hline No. & $\begin{array}{c}\text { Faktor } \\
\text { Produksi }\end{array}$ & Satuan & Input aktual & \multicolumn{1}{c}{$\begin{array}{c}\text { Input } \\
\text { optimum }\end{array}$} & Perubahan \\
\hline Luas $\mathbf{1 5 0}$ m $^{2}$ & & & & \\
1. $\quad \mathrm{X}_{1}$ & $\mathrm{~kg}$ & 38,89 & 66,80 & 27,91 \\
2. $\quad \mathrm{X}_{2}$ & $\mathrm{~kg}$ & 61,94 & 173,70 & 111,76 \\
3. $\quad \mathrm{X}_{3}$ & $\mathrm{~kg}$ & 12,50 & 3,70 & 8,80 \\
4. $\quad \mathrm{X}_{4}$ & hok & 18,41 & $-0,62$ & 19,03 \\
\hline Luas $\mathbf{1 . 0 0 0} \mathrm{m}^{2}$ & & & & \\
1. $\quad \mathrm{X}_{1}$ & $\mathrm{~kg}$ & 259,39 & 455,56 & 196,17
\end{tabular}




$\begin{array}{rllrrr}\text { 2. } & \mathrm{X}_{2} & \mathrm{~kg} & 413,17 & 1.158,59 & 745,42 \\ \text { 3. } & \mathrm{X}_{3} & \mathrm{~kg} & 83,38 & 24,68 & 58,7 \\ \text { 4. } & \mathrm{X}_{4} & \text { hok } & 122,79 & -4,14 & 126,93\end{array}$

Sumber: Analisis Data Primer, 2019

Berdasarkan tabel 4, penggunaan rata-rata benih pada usaha ikan mujair yang dilakukan oleh Pokdakan Ulam Sari Makmur adalah sebesar 38,89 kg. Jumlah tersebut perlu ditambah agar tercapai kondisi yang optimum, penambahan yang dilakukan adalah sebesar $27,91 \mathrm{~kg}$ sehingga penggunaan optimum benih adalah sebesar $66,8 \mathrm{~kg}$. Hal ini dikarenakan luasan kolam $150 \mathrm{~m}^{2}$ harus dimanfaatkan secara maksimal.

Menurut Prahasta (2009), setiap meter persegi kolam dapat diisi benih sebanyak 5-10 ekor untuk ukuran benih sebesar 5-8 cm, maka untuk $150 \mathrm{~m}^{2}$ paling tidak harus terisi benih ikan sebanyak 750 ekor benih dan maksimal sebanyak 1.500 ekor benih. Apabila setiap kilogram benih yang dibeli oleh anggota pokdakan berisi kurang lebih 30 ekor, dengan harapan hidup ikan sekitar $90 \%$ dari jumlah benih yang ada, maka penggunaan benih sebesar 38,89 $\mathrm{kg}$ (dibulatkan menjadi $39 \mathrm{~kg}$ ) sehingga benih yang tersisa hanya sekitar 1.000 ekor. Dari kondisi tersebut, input optimal yang harus digunakan adalah sebanyak $66,8 \mathrm{~kg}$ (dibulatkan menjadi $67 \mathrm{~kg}$ ), sehingga jumlah benih optimum yang harus digunakan sebanyak 1.800 ekor $/ 150 \mathrm{~m}^{2}$. Namum menurut Badan Standardisasi Nasional (2009), padat penebaran untuk pembesaran ikan mujair untuk ukuran standar nasional sebaiknya diantara 5-7 ekor $/ \mathrm{m}^{2}$ sehingga padat penebaran yang sesuai dengan rekomendasi adalah sebanyak 750 ekor hingga 1.050 ekor benih untuk luasan $150 \mathrm{~m}^{2}$ atau 5.000 ekor hingga 7.000 ekor untuk luasan $1.000 \mathrm{~m}^{2}$ yang merupakan luas kolam ideal untuk melakukan pembesaran ikan mujair.

Penggunaan rata-rata pelet pada usaha ikan mujair yang dilakukan oleh Pokdakan Ulam Sari Makmur adalah sebesar 61,94 kg/150m². Jumlah tersebut perlu ditambah agar tercapai kondisi yang optimum, penambahan yang dilakukan adalah sebesar 111,76 kg sehingga penggunaan optimum pelet adalah sebesar $173,7 \mathrm{~kg}$. Penambahan jumlah pelet mengikuti penambahan jumlah benih. Namun menurut Badan Standardisasi Nasional (2009), pemberian pakan untuk ikan mujair yang berukuran di atas 3 bulan berbeda dengan kondisi ikan 
Utami et.al. / Jurnal Dinamika Sosial Ekonomi Vol.20 No.1, Juni 2019

mujair berukuran di bawah 3 bulan, pemberian pakan pembesaran ikan untuk di bawah 3 bulan harus diberikan sebanyak 5\% dari biomassa ikan, tetapi untuk bulan ke 4 diharuskan sebanyak 2\% dari biomassa ikan. Dari hal tersebut, penggunaan pakan optimum yang digunakan tidak sesuai dengan standar pemberin pakan yang direkomendasikan oleh BSN.

Penggunaan rata-rata dolomit pada usaha ikan mujair yang dilakukan oleh Pokdakan Ulam Sari Makmur adalah sebesar 12,50 kg. Jumlah tersebut perlu dikurangi agar tercapai kondisi yang optimum, pengurangan yang dilakukan adalah sebesar $8,80 \mathrm{~kg}$ sehingga penggunaan optimum dolomit adalah sebesar $3,70 \mathrm{~kg}$. penggunaan dolomit seharunya memiliki pengaruh terhadap produksi ikan mujair. Namun penggunaannya yang berlebihan tidak baik untuk kondisi perairan di kolam. Menurut Pudjiharta (2009), lokasi Desa Kebocoran yang letaknya di kaki Gunung Slamet memiliki pH tahan sebesar 4,5-6 (agak masam). Oleh karenanya, penggunaan dolomit tidak perlu digunakan terlalu berlebihan karena $\mathrm{pH}$ tanah di Desa Kebocoran sudah mendekati kondisi $\mathrm{pH}$ netral.

Penggunaan rata-rata tenaga kerja pada usaha ikan mujair yang dilakukan oleh Pokdakan Ulam Sari Makmur adalah sebesar 18,41 hok. Jumlah tersebut perlu dikurangi agar tercapai kondisi yang optimum. Penggunaan tenaga kerja dinilai tidak efisien karena alokasi penggunaan jam kerja tenaga kerja dalam keluarga jumlahnya terlalu berlebihan, sehingga tenaga kerja yang seharusnya berpengaruh terhadap produksi ikan mujair menjadi tidak berpengaruh.

Faktor-faktor produksi yang tidak efisien disebabkan penggunaan jumlah faktor produksi oleh sebagian besar pembudidaya berdasarkan atas perkiraan. Oleh karena itu perlu adanya upaya penyuluhan yang lebih intensif bagi pembudidaya agar penggunaan faktor produksi bisa sesuai dengan standar, dengan harapan memperoleh keuntungan yang maksimal.

Berdasarkan hasil analisis, guna meningkatkan produksi dari kondisi aktual menjadi kondisi optimum perlu dilakukan perubahan penggunaan input faktor produksi, tetapi hal yang perlu diperhatikan adalah keadaan kondisi 
wilayah tempat pembesaran ikan mujair dan rekomendasi standar nasional pembesaran ikan mujair yang direkomendasikan oleh Badan Standardisasi Nasional (BSN) atau dinas terkait lainnya, agar mutu dan kualitas produksi ikan mujair dapat meningkat.

\section{KESIMPULAN DAN SARAN}

\section{Kesimpulan}

Faktor produksi benih dan pakan pelet berpengaruh positif terhadap produksi ikan mujair, sedangkan dolomit dan tenaga kerja tidak berpengaruh terhadap produksi ikan mujair. Penggunaan faktor produksi benih dan pelet tidak optimum, perlu dilakukan penambahan input, sehingga jumlah optimumnya menjadi sebesar $66,8 \mathrm{~kg} / 150 \mathrm{~m}^{2}$ dan $173,7 \mathrm{~kg} / 150 \mathrm{~m}^{2}$ serta penggunaan faktor produksi dolomit dan tenaga kerja belum optimum, perlu dilakukan pengurangan input sehingga jumlah optimumnya sebesar $3,70 \mathrm{~kg} / 150 \mathrm{~m}^{2}$ dan $-0,62$ hok.

\section{Saran}

Penggunaan input optimum untuk benih, pelet, dan dolomit juga harus diimbangi dengan rekomendasi dari dinas terkait seperti Badan Standardisasi Nasional (BSN) atau instansi lainnya berhubungan dengan pembesaran ikan mujair, agar penggunaan input sesuai dengan penggunaan yang ideal sehingga produksi yang dihasilkan akan lebih maksimal. Selain itu lebih memperhatikan mengenai teknik budidaya pembesaran ikan mujair agar sesuai dengan yang disarankan oleh BSN.

\section{DAFTAR PUSTAKA}

Badan Standardisasi Nasional. 2009. SNI Pembesaran Ikan Kelas Pembesaran di Kolam Air Tenang. Bogor: Badan Standardisasi Nasional.

Fajriati, Aprilia. 2018. Analisis Efisiensi Produksi Budidaya Ikan Nila Merah di Kabupaten Klaten. Jurnal Peran Keanekaragaman Hayati untuk Mendukung Indonesia Sebagai Lumbung Pangan Dunia, 2 (1) : 65-74.

Hidayatullah, Arief. 2016. Analisis Faktor-Faktor Yang Mempengaruhi Produksi Usaha Ikan Mas di Kecamatan Babirik Kabupaten Hulu Sengai Utara. Jurnal Al Ulum Sains dan Teknologi, 2 (1) : 14-19. 
Utami et.al. / Jurnal Dinamika Sosial Ekonomi Vol.20 No.1, Juni 2019

Kementerian Kelautan dan Perikanan. 2017. Laporan Tahunan Kementerian Kelautan dan Perikanan Republik Indonesia. Jakarta: Kementerian Kelautan dan Perikanan RI.

Negara, A. A. Ngurah Bagus Surya. 2017. Faktor-faktor Yang Mempengaruhi Produksi Budidaya Ikan Lele di Kota Denpasar. Jurnal Ekonomi dan Bisnis Universitas Udayana, 6 (2) : 755-788.

Prahasta, Arief. 2009. Budidaya Usaha Pengolahan Agribisnis Ikan Mujair. Bandung: Pustaka Grafika.

Pudjiharta, A. 2009. Pengaruh Penggunaan Lahan Hutan Terhadap hasil Air di Baturraden. Jurnal Penelitian Hutan dan Konversi Alam, 7 (2), 119-126.

Riani. 2018. Analisis Efisiensi Alokatif Usaha Tani Tambak Ikan Bandeng (Chanos Chanos F) Di Kabupaten Aceh Utara. Jurnal AGRIFO, 3 (1), 69-78.

Soekartawi. 2016. Analisis Usahatani. Jakarta: Universitas Indonesia (UI-Press)

Sumartin. 2017. Efisiensi Faktor-Faktor Produksi Usaha Budidaya Ikan Lele Dumbo (Clarias garipenus): Studi Kasus Pada Alumni Peserta Pelatihan Budidaya Ikan DI BPPP Banyuwangi. Samakia: Jurnal Ilmu Perikanan, 8 (2) :06-16.

Sumartin. 2018. Analisis Efisiensi Faktor-Faktor Produksi Usaha Budidaya Ikan Patin (Pangisius pangasius) Studi Kasus Pada Alumni Peserta Pelatihan Budidaya Ikan Di BPPP Banyuwangi. Intek Akuakultur, 2 (1) : 16-34. 